\title{
The effect of using the Wheatley model for constructive learning on cognitive achievement and the performance level of some skills of playing with the opposite side of racket in Field Hockey
}

*Dr/ Ahmed Adel Tameem Mohamed

Introduction and research problem:

that the modern view of science includes complementarity between the cognitive and behavioral aspects. So attention must be paid to these aspects. It is necessary to care for building the personality of the learner in terms of cognitive, emotional and skillful sides. Thus the learner gains experience to modify his behavior. (7: 11)

and that the usual method doesn't give room for exploration and innovation on the part of the learner. Furthermore, active participation in education leads to a better retention of information and a good understanding. (1:28)

The Wheatley model is an educational tool that builds knowledge and manages practical learning issues. It emphasizes the interaction between concepts and knowledge of skill and between actions and procedural steps.

And that the basic skills in hockey as the attacker when shooting one of the skills of playing the reverse face of the striker on the goal does not expect the defender that, and they are surprising to the defenders and the goalkeeper. (4:182)

The problem of this research is that the researcher has noticed that the college students 'performance has a lot of mistakes, despite the availability of material and human capabilities to some extent. Accordingly, the role of the teacher is to present a problem that attracts the learners. Then he allows them to work until they solve the problem. Based on the foregoing, the researcher realizes the importance of using the Wheatley model for achieving the goals of the educational process in Field hockey. He combined the theoretical content and practical application. Also he considers the capabilities and

* Lecturer at the Department of Curricula and Physical Education, Faculty of Physical Education, Asyut University, Egypt. 
tendencies of learners and their active participation in education.

Research Aim:

The research aims to identify the effect of using the Wheatley model for constructive learning on cognitive achievement and the performance level of some skills of playing with the opposite side of racket in Field hockey.

\section{Research Hypotheses:}

1- There are statistically significant differences between the average grades of the pre and post measurements of the experimental group in the performance level of some skills of playing with the opposite side of racket in the research sample in favor of post measurement.

2- There are statistically significant differences between the average grades of the pre and post measurements of the experimental group in the cognitive achievement of the research sample in favor of post measurement.

Research procedures:

Research Methodology:

The researcher used the experimental methodology with the experimental design for every group in the pre and post measurements, due to their suitability for the nature of the research.

Research Community and Sample:
The research community included the second year students at the Faculty of Physical Education - Asyut University for the academic year (2018/2019). The researcher selected the research sample in a random manner. The total amount of the sample reached (60) students, including (40) students for the basic sample, (20) students for the exploratory study.

\section{Data Collection Methods:}

First: The Tools and Equipment:

Resta Meter, Medical Scale, Stop Watch, Measuring Tape, Drawer Box, and Hockey Rackets and Balls.

\section{Second: The Used Tests:}

- $\quad$ Measuring growth rates (age, height, weight), Advanced IQ Tests, Physical ability tests, Skills tests, Cognitive Achievement Test.

\section{Third: Forms:}

- Data registration forms, Cognitive test axes form, Cognitive test vocabulary form

Statistical characterization of the Research Sample:

The researcher found similarities in the light of the following variables: growth rates (age - height - weight), advanced intelligence, physical abilities, skill tests and cognitive achievement test . Table (1) clarifies that.

Table (1)

Assiut Journal For Sport Science Arts 
Arithmetic mean, median, standard deviation, skewness coefficient for growth rates, advanced intelligence test, physical tests, and skill tests for the sample $(n=40)$

\begin{tabular}{|c|c|c|c|c|c|c|c|}
\hline M & \multicolumn{2}{|c|}{$\begin{array}{l}\text { Research } \\
\text { Variables }\end{array}$} & $\begin{array}{c}\text { Unit of } \\
\text { Measurement } \\
\end{array}$ & $\begin{array}{c}\text { Arithmetic } \\
\text { Mean } \\
\end{array}$ & Median & $\begin{array}{l}\text { Standard } \\
\text { Deviation } \\
\end{array}$ & $\begin{array}{l}\text { Skewness } \\
\text { Coefficient } \\
\end{array}$ \\
\hline 1 & \multicolumn{2}{|l|}{ Age } & Year / month & $r . .0$ & $r \cdot \cdots$ & $\because 0$ & .11 \\
\hline 2 & \multicolumn{2}{|l|}{ Height } & Centimeters & IVT.IA & IVะ... & 1.19 & $.0 Y_{-}$ \\
\hline 3 & \multicolumn{2}{|l|}{ Weight } & $\mathrm{Kg}$ & 71.01 & 79.0. & r... & $\because \wedge \cdot-$ \\
\hline 4 & \multicolumn{2}{|c|}{$\begin{array}{l}\text { Advanced } \\
\text { Intelligence }\end{array}$} & Degree & $\sum 1 . \lambda r$ & $\varepsilon r .$. & $1.1 \mathrm{~V}$ & $.1 \varepsilon_{-}$ \\
\hline \multirow[b]{2}{*}{5} & \multirow{6}{*}{$\begin{array}{l}\text { Physical } \\
\text { Tests }\end{array}$} & $\begin{array}{l}\begin{array}{l}\text { Fist } \\
\text { strength } \\
\text { (right) }\end{array} \\
\end{array}$ & $\overline{\mathrm{Kg}}$ & $r \leqslant .10$ & ro... &.$\wedge r$ &.$\wedge r_{-}$ \\
\hline & & $\begin{array}{l}\text { Fist } \\
\text { strength } \\
\text { (left) }\end{array}$ & $\mathrm{Kg}$ & rq.9. & $r . .$. &.$\wedge \mathrm{V}$ & $\cdot .9 \leq$ \\
\hline 6 & & $\begin{array}{l}\text { Standing } \\
\text { Broad } \\
\text { Jump }\end{array}$ & Meter & $1 . \wedge \wedge$ & 1.19 & $.1 \cdot$ & . \\
\hline 7 & & $\begin{array}{l}\text { Running } \\
30 \mathrm{~m} \text { from } \\
\text { High Start }\end{array}$ & Second & $\varepsilon .9 \leq$ & $0 . \cdot \varepsilon$ &.$r$. & $.7 V_{-}$ \\
\hline 8 & & $\begin{array}{l}\text { Pro } \\
\text { Agility } \\
\text { Test with } \\
\text { Hockey } \\
\text { Stick } \\
\end{array}$ & Second & 9.90 & $9 . \vee 9$ &.$v^{\prime}$ & $\cdot . \Sigma V$ \\
\hline 9 & & $\begin{array}{l}\text { Standing } \\
\text { Forward } \\
\text { Bend }\end{array}$ & $\mathrm{CM}$ & $0 . r$ & $0 . \cdots$ &.$\wedge \mathrm{V}$ &. Y人 \\
\hline 10 & \multirow{6}{*}{$\begin{array}{l}\text { Skill } \\
\text { Tests }\end{array}$} & $\begin{array}{l}\text { Test to } \\
\text { measure the } \\
\text { Strength of } \\
\text { pushing the } \\
\text { ball }\end{array}$ & Meter & r.01 & r.o. & . & $\because Y V_{-}$ \\
\hline 11 & & $\begin{array}{l}\text { Test to } \\
\text { measure the } \\
\text { speed of } \\
\text { pushing the } \\
\text { ball }\end{array}$ & Second & $11 . \leq 0$ & $11 . \cdots$ & $\because 0$ & $\because Y^{\prime}$ \\
\hline 12 & & $\begin{array}{l}\text { Test to } \\
\text { measure the } \\
\text { precision of } \\
\text { pushing the } \\
\text { ball }\end{array}$ & Number & $1 . r o$ & $1 . \cdots$ &.$\leqslant \wedge$ & .70 \\
\hline 13 & & $\begin{array}{l}\text { Test to } \\
\text { measure } \\
\text { the } \\
\text { Strength } \\
\text { of hitting } \\
\text { the ball }\end{array}$ & Meter & $1 \leqslant . \leqslant 7$ & $1 \leqslant 0$. & 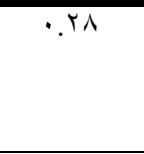 & $\cdot r \cdot-$ \\
\hline 14 & & $\begin{array}{l}\text { Test to } \\
\text { measure } \\
\text { the } \\
\text { speed of } \\
\text { hitting } \\
\text { the ball }\end{array}$ & Number & r.r人 & r... & $\because \leqslant 9$ & $.0 \leqslant$ \\
\hline 15 & & $\begin{array}{l}\text { Test to } \\
\text { measure } \\
\text { the } \\
\text { precision } \\
\text { of hitting } \\
\text { the ball }\end{array}$ & Number & 1.10 & $1 . \cdots$ & 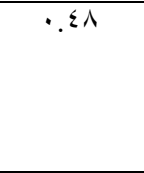 & .70 \\
\hline
\end{tabular}

\section{Follow Table (1)}


Arithmetic mean, median, standard deviation, skewness coefficient for growth rates, advanced intelligence test, physical tests, and skill tests for the sample $(n=40)$

\begin{tabular}{|c|c|c|c|c|c|c|}
\hline $\mathrm{M}$ & $\begin{array}{l}\text { Research } \\
\text { Variables }\end{array}$ & \begin{tabular}{|c|} 
Unit of \\
Measurement \\
\end{tabular} & $\begin{array}{c}\text { Arithmetic } \\
\text { Mean }\end{array}$ & Median & $\begin{array}{l}\text { Standard } \\
\text { Deviation } \\
\end{array}$ & $\begin{array}{c}\text { Skewness } \\
\text { Coefficient } \\
\end{array}$ \\
\hline 16 & $\begin{array}{l}\text { Test for } \\
\text { receiving } \\
\text { the ball } \\
\text { below } \\
\text { with the } \\
\text { opposite } \\
\text { side of } \\
\text { racket } \\
\text { from } \\
\text { pushing } \\
\text { the ball. }\end{array}$ & Number & T. $\leqslant 0$ & r... & $\because .0$ & $r^{r}$ \\
\hline 17 & $\begin{array}{l}\text { Test for } \\
\text { receiving } \\
\text { the ball } \\
\text { below } \\
\text { with the } \\
\text { opposite } \\
\text { side of } \\
\text { racket } \\
\text { from } \\
\text { hitting } \\
\text { the ball. }\end{array}$ & Number & r.r. & r... & $\cdot . \leqslant 7$ & .91 \\
\hline 18 & Cognitive test & Degree & $r .94$ & r.A. & $r .10$ & $\cdot . \Delta \Gamma$ \\
\hline & \multirow{2}{*}{\multicolumn{2}{|c|}{$\begin{array}{llr}\text { Table } & (1) & \text { shows } \\
\text { rities } & \text { among } & \text { the }\end{array}$}} & \multirow{2}{*}{\multicolumn{4}{|c|}{$\begin{array}{lcc}\text { must be open questions } & \text { that } \\
\text { allow } & \text { discussion } & \text { and }\end{array}$}} \\
\hline & & & & & & \\
\hline & \multirow{2}{*}{\multicolumn{2}{|c|}{$\begin{array}{l}\text { dividuals of the research } \\
\text { mple in the selected } \\
\text { easurements, The Skewness }\end{array}$}} & \multicolumn{4}{|c|}{$\begin{array}{l}\text { communication. } \\
\text { Cooperating Groups: }\end{array}$} \\
\hline & & & \multirow{4}{*}{\multicolumn{4}{|c|}{$\begin{array}{l}\text { When students work in } \\
\text { groups, they have the } \\
\text { opportunities to generate new } \\
\text { ideas. Working in small groups } \\
\text { gives the students cognitive } \\
\text { roles and helps them discover } \\
\text { the problem together. In this } \\
\text { study, the students were }\end{array}$}} \\
\hline & \multicolumn{2}{|c|}{$\begin{array}{l}\text { oefficient ranged between }( \pm \\
\text { It indicates that the research }\end{array}$} & & & & \\
\hline & \multicolumn{2}{|c|}{$\begin{array}{l}\text { ample is homogeneous and } \\
\text { epresents a natural moderate } \\
\text { ociety. }\end{array}$} & & & & \\
\hline & \multicolumn{2}{|c|}{$\begin{array}{l}\text { heatley Model for Teaching } \\
\text { kills of the Research: }\end{array}$} & & & & \\
\hline & \multirow{2}{*}{\multicolumn{2}{|c|}{$\begin{array}{l}\text { questions about the skill have } \\
\text { been prepared for the students. } \\
\text { These questions lead them to }\end{array}$}} & \multicolumn{4}{|c|}{ group has eight students. } \\
\hline & & & \multirow{2}{*}{\multicolumn{4}{|c|}{$\begin{array}{l}\text { through experimentation and } \\
\text { not only theoretical discussion } \\
\text { (practical implementation). } \\
\text { Participation: }\end{array}$}} \\
\hline & \multicolumn{2}{|c|}{$\begin{array}{l}\text { establish effective ways of } \\
\text { thinking about the skill. They }\end{array}$} & & & & \\
\hline
\end{tabular}


After that students apply the new concepts and design exercises to implement their suggestion and practice the skill. Every group has the necessary tools to do the lesson and implement the practical side in the light of the attained concepts and knowledge.

Survey Study:

The

researcher

conducted the survey from Sunday 23/9/2018 to Thursday $4 / 10 / 2018$, on (20) students from inside the original community and outside the basic research sample. This is to ensure the validity of the research tools and find the scientific processes (honesty and consistency) of the skills. The Wheatley model shows the students' understanding of the skills and the validity of the place.

\section{Pre Measurement:}

The pre-measurement was performed on the research group from Sunday 14/10/2018 to Monday 15/10/2018.

\section{Basic Experiment:}

The researcher applied the Wheatley model on the research sample from Sunday 21/10/2018 to Thursday $29 / 10 / 2018$. The unit time is (120) minutes for (6) weeks. The introductory and final parts were taught according to the established curriculum. The researcher taught the research sample.

\section{Post Measurement:}

The post measurement was performed on the skill tests from Sunday 2/12/2018 to Monday 3/2/2018.

\section{The Used Statistical}

\section{Operations:}

The

researcher performed the scientific operations using the Statistical Package for Social Sciences (SPSS) program, through the following statistical information:

Arithmetic mean, Standard Deviation, Median, Skewness Coefficient, Correlation Coefficient, Test (T) to indicate the differences, The Percentage, The Rate of Improvement.

\section{Presentation and Discussion of the Results:}

In the light of the research hypotheses, the researcher presents the attained results:

The Results of the First Hypothesis: There are statistically significant differences between the average grades of the pre and post measurements of the experimental group in the 
performance level of some skills of playing with the opposite side of racket in the research sample in favor of post measurement.

\section{Table (2)}

\section{Significance of the differences between the pre and post mean} averages in the skill variables $(n=40)$

\begin{tabular}{|c|c|c|c|c|c|c|}
\hline \multirow{2}{*}{ Measurement } & \multirow{2}{*}{$\begin{array}{c}\text { Unit of } \\
\text { Measurement }\end{array}$} & \multicolumn{2}{|c|}{ Pre Measurement } & \multicolumn{2}{|c|}{ Post Measurement } & \multirow{2}{*}{$\begin{array}{c}\text { (T) } \\
\text { Value }\end{array}$} \\
\hline & & $\begin{array}{c}\text { Arithmetic } \\
\text { mean }\end{array}$ & $\begin{array}{l}\text { Standard } \\
\text { Deviation }\end{array}$ & $\begin{array}{c}\text { Arithmetic } \\
\text { mean }\end{array}$ & $\begin{array}{l}\text { Standard } \\
\text { Deviation }\end{array}$ & \\
\hline $\begin{array}{l}\text { Test to measure } \\
\text { the Strength of } \\
\text { pushing the ball } \\
\text { with the opposite } \\
\text { side of racket }\end{array}$ & Meter & T.01 & $\cdot r$ & $9 . \varepsilon$. & ו & 1.10 \\
\hline $\begin{array}{l}\text { Test to measure } \\
\text { the speed of } \\
\text { pushing the ball } \\
\text { with the opposite } \\
\text { side of racket }\end{array}$ & Second & $11 . \leqslant 0$ & .0 . & $1 \leq .7 \pi$ & $\cdot \wedge V$ & Q. . . \\
\hline $\begin{array}{l}\text { Test to measure } \\
\text { the precision of } \\
\text { pushing the ball } \\
\text { with the opposite } \\
\text { side of racket }\end{array}$ & Number & $1 . r 0$ & $\cdot . \leqslant \wedge$ & r.o. & .01 & $\vee .71$ \\
\hline $\begin{array}{l}\text { Test to measure } \\
\text { the Strength of } \\
\text { hitting the ball } \\
\text { with the opposite } \\
\text { side of racket }\end{array}$ & Meter & $1 \leq . \leq 7$ & 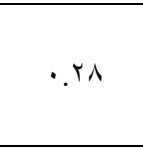 & $r \cdot .0$. & .01 & १.Vץ \\
\hline $\begin{array}{l}\text { Test to measure } \\
\text { the speed of } \\
\text { hitting the ball } \\
\text { with the opposite } \\
\text { side of racket }\end{array}$ & Number & 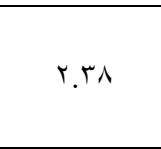 & $\cdot \leqslant 9$ & $0 . \leqslant 1$ & .01 & 1. $1 \leq$ \\
\hline $\begin{array}{l}\text { Test to measure } \\
\text { the precision of } \\
\text { hitting the ball } \\
\text { with the opposite } \\
\text { side of racket }\end{array}$ & Number & 1.50 & $\cdot . \leqslant 1$ & $\varepsilon .0 r$ & .01 & ᄉ. $\varepsilon q$ \\
\hline $\begin{array}{l}\text { Test for receiving } \\
\text { the ball below } \\
\text { with the opposite } \\
\text { side of racket } \\
\text { from pushing the } \\
\text { ball. }\end{array}$ & Number & $r_{.} \leqslant 0$ & $\because 0$. & $V . \varepsilon r$ & $\because 0$. & $9 . V Y$ \\
\hline $\begin{array}{l}\text { Test for receiving } \\
\text { the ball below } \\
\text { with the opposite } \\
\text { side of racket } \\
\text { from hitting the } \\
\text { ball. }\end{array}$ & Number & r.r. & $\because \leqslant 7$ & $V . \leqslant 1$ & $\because .01$ & $9 .+r$ \\
\hline
\end{tabular}

The value of (T) at degree (39) and significance level $(0.05)=1.697$ As table (2) The level (0.05)Between the pre presence of statistically and post average averages in significant differences at the the skill performance tests of 
the skills under consideration in favor of post measurement.

Explanation and Discussion of the First Hypothesis Results:

The skill performance of the experimental group improved after using the Wheatley model which encourages discussion and argument. Thus students participate positively in the educational process and they are able to discover the performance and sequence of the skills. Also they realize the relationship between concepts and principles during answering the teacher's questions.

And that the Wheatley model encourages the learners' mental capabilities and develops their practical skills. The Wheatley model establishes an effective learning environment that allows learners to share their ideas in a small group. Thus it leads to a kind of successful interaction and actual intellectual participation, and sees Mahmoud Abdel Halim Abdel Karim (2006) That the problem is presented to students in the form of a question or phrase that challenges and stimulates students 'thought and interest. $(8: 265)$

The role of the teacher in this step is guidance and guidance, as it passes over the working groups and sometimes directs some groups to reestimate and reflect on what they have reached. $(9: 20)$

The researcher points out the positive impact of the Wheatley model. It helps students achieve the goals in a way that suits their capabilities and needs. They become more positive and active with their teacher and colleagues. The Wheatley model allows them to work in groups and develop some exercises to learn and apply the skill. They can employ their efforts and exert more effort without feeling bored. The Wheatley model helps to form a correct perception of all parts of the skill and to remember its parts. This is supported by the studies of "(2011) (3), (2010) (5) and (2002) (10)". The results of these studies confirmed the effectiveness of using the Wheatley model in learning.

The researcher believes that students play a positive role in the educational process which leads to the development of their abilities. Thus the validity

Assiut Journal For Sport Science Arts 
of the first hypothesis is achieved.

The Results of the Second Hypothesis: There are statistically significant differences between the average grades of the pre and post measurements of the experimental group in the cognitive achievement

of the research sample in favor of post measurement.

Table (3)

The Statistically Significant differences between the average grades of the pre and post measurements in the cognitive achievement of Field Hockey $(\mathrm{N}=40)$

\begin{tabular}{l|c|c|c|c|c|c}
\hline \hline Measurement & \multirow{2}{*}{$\begin{array}{c}\text { Unit of } \\
\text { Measurement }\end{array}$} & \multicolumn{2}{|c|}{ Pre Measurement } & \multicolumn{2}{|c|}{ Post Measurement } & (T) \\
\cline { 3 - 6 } & & $\begin{array}{c}\text { Arithmetic } \\
\text { mean }\end{array}$ & $\begin{array}{c}\text { Standard } \\
\text { Deviation }\end{array}$ & $\begin{array}{c}\text { Arithmetic } \\
\text { mean }\end{array}$ & $\begin{array}{c}\text { Standard } \\
\text { Deviation }\end{array}$ & \\
\hline \hline $\begin{array}{l}\text { Cognitive } \\
\text { achievement }\end{array}$ & Degree & 22.90 & 2.61 & 54.22 & 3.89 & 13.24 \\
\hline \hline
\end{tabular}

The value of (T) at degree (39) and significance level $(0.05)=1.697$

As table (3) shows, there are statistically significant differences at level (0.05) in the In the cognitive achievement of field hockey, which is greater than the tabular value at level (0.05).

Explanation and Discussion of the Second Hypothesis Results:

Through its findings, the Wheatley model contains many and varied information and knowledge about the history, law, and skill performance of hockey, this resulted in students acquiring the largest amount of information leading to a high rate of retrieval of this information in different situations, where each of the " Mohamed Saad Zaghloul, others"(2001) that the use of educational technology leads to an increase in the impact of the information students have learned and entrenched in their minds, which is reflected in the learning process. $(6 ; 19)$

The researcher attributes the reason for the progress of the experimental group members in the level of cognitive achievement to the use of a model followed by learning skills because it helps in discussion and dialogue, which allows positive participation in the educational process as it makes students able to discover the performance of the skills and their sequence and access to concepts and principles and realize the relationship between 
them through answer To the teacher's questions.

The researcher believes that the students 'access to the cognitive requirements of the skill by itself makes the information difficult to forget, and this leads to an increase in cognitive achievement, and this is consistent with the results of the study of" (2011) (3), (2005) (2), (2002) (10), whose results confirmed that the Wheatley model helps to increase cognitive achievement and plays a positive role in the educational process which leads to the development of their thinking abilities, Thus the validity of the second hypothesis is achieved.

\section{Conclusions:}

1- Using the Wheatley model showed an improvement in the skill performance level of the experimental group.

2- $\quad$ The Wheatley model had an effect on cognitive achievement and skill performance level in Field hockey, which indicates its effectiveness and impact.

\section{Recommendations:}

1- Applying the Wheatley model in learning basic skills of Field hockey on students of the Faculty of Physical Education, Asyut University.
2- Conducting similar studies using the Wheatley model with different age stages and other activities to confirm the effectiveness of the method.

3-Updating the methods of learning in the curriculum of Field hockey because of its importance in improving the level of performance.

\section{List of References:}

\section{First: Arabic References:}

1- Hassan Hussein Zaitoun, Kamal Abdel Hamid Zaitoun (2003): Learning and Teaching from a Constructive Perspective, the Book World, Cairo.

\section{2- Sahara Abdel-Karim}

(2005): The effectiveness of teaching at the University of Notesky, and follows in achieving some physical concepts and the ability to infer formal thinking for students of the first secondary class students, the Egyptian Association for Scientific Education, the fourth scientific conference, scientific education for all, Ismailia from July 31 August 3, Volume 1.

\section{3- Fatima Mohamed Fleifel,} Mervat Samir Hussein (2011): The Effect of Using the Wheatley Model in the Cognitive Achievement and Performance Level of some Skills of Physical Education Lesson, Minya Journal of 
Physical Education Sciences, Volume IV, First Issue.

4- Mohamed

Ahmad

Abdullah (2006): Comprehensive preparation for hockey players, Ayat Center for Printing and Computer, Zagazig.

5- Mohamed Bin Barjas AlShahrani (2010): The Effect of Using the Wheatley Model in Teaching Mathematics on Academic Achievement of Sixth-grade Primary Students, unpublished $\mathrm{PhD}$ thesis, College of Physical Education, Umm Al-Qura University, Saudi Arabia.

6- Mohamed Saad Zaghloul, Makarem Abu Harajah, Hani Saeed Abdel Moneim (2001): Educational Technology and its Methods in Physical Education, The Book Center for Publishing, Cairo.

7- Mohamed Mahmoud AlHaila (2003): Teaching Methods and Strategies, University Book House, Part Three, United Arab Emirates.
8- Mahmoud Abdel Halim Abdel Karim (2006): The Dynamics of Teaching Physical Education, The Book Center for Publishing, Cairo.

9- Mona Abdel-Sabour Mohamed (2004): The Systematic Approach and Some Teaching Models Based on Structural Thought, The Fourth Arab Conference on "The Systematic Approach to Teaching and Learning, April.

10- Maha Abdul Salam alKhamisi (2002): The Effect of Using both the Wheatley Model for Constructive Learning and Learning by Reception for Developing Achievement and Processes of Science and Innovative Thinking for Fifth-grade Primary School Students in the Subject of Science, unpublished doctoral dissertation, College of Girls, Ain Shams University. 